\title{
HERE COMES PANKOWSKI. ADVENTURES IN AMBIGUITY
}

\begin{abstract}
The article offers a description of the rich literary output of the Polish writer Marian Pankowski and of the winding path his works have traversed over the past decades both in Western Europe and in his homeland. Its main assumption is that the peculiarities of Pankowski's reception in Poland and abroad appear to be bound up with the artistic and ideological choices the author of Rudolf has made throughout his long-lasting career as a poet, playwright and novelist. The general description serves as a background for the introduction of the ten papers of which this special issue dedicated to Pankowski's ambiguous literary output consists.
\end{abstract}


"Though regarded in Western Europe as one of the most original writers of the twentieth century, his iconoclastic positions, particularly toward the Catholic Church and its teachings, have limited his publishing in his native country." Although undoubtedly exaggerated, these words of praise appearing on the back of the 1996 American edition of Marian Pankowski's novel Rudolf nicely illustrate the winding path the works of the Polish émigré writer have traversed over the past five decades. In fact, the relatively marginal position of Pankowski in his home country has changed only in recent years, when his writings started to gain increasing visibility in Polish literary scholarship and increasing recognition among literary critics. To a certain extent, the peculiarities of Pankowski's reception in Poland and abroad appear to be bound up with the artistic and ideological choices the author of Rudolf has made throughout his long-lasting career as a poet, playwright and novelist. In the mean time, the recent rise of interest in Pankowski's literary output in his native country seems to suggest that his provocative writings have come to play a significant role in the culture war between secular progressives and Catholic traditionalists that has unfolded in Poland in the aftermath of the fall of communism. ${ }^{1}$

Marian Pankowski was born on November 9, 1919, in Sanok, a small Carpathian town inhabited by Poles, Jews, and Ukrainians. In 1938, he enrolled as a student of Polish Philology at the Jagiellonian University in Krakow and made his debut as a poet on the pages of the leftist, Lwów-based cultural periodical Sygnaty (Signals). His academic education was soon to be interrupted by the outbreak of the Second World War. After having fought in the ranks of the Polish army during the September Campaign, Pankowski was arrested in 1942 by the Gestapo on charges of belonging to the underground army Związek Walki Zbrojnej (Union of Armed Struggle). He was first sent to Auschwitz and subsequently detained in Gross-Rosen, Nordhausen and Bergen-Belsen. In April 1944, Pankowski was liberated from the Nazi camp in Bergen-Belsen and transferred to Belgium, where he continued his education (at the Université Libre de Bruxelles) and obtained a PhD in Slavic Philology (with a dissertation on the Polish Modernist poet Bolesław Leśmian). While increasingly combining his academic duties with a wide variety of literary endeavors, Pankowski was eventually appointed lecturer of Polish language and literature at his Francophone Alma Mater. After his retirement in the early 1980s, he remained settled in the Belgian capital, where he died in the early spring of 2011.

Pankowski's early literary career has often been described - not the least by the author himself - in terms of a gradual shift from the writing of "innocent" ${ }^{2}$ lyrics toward the writing of potentially provocative and offensive pieces of prose and theatre. In the early postwar years, his literary activities predominantly revolved around poetry and translations of poetry (mainly from Polish into French and vice versa). At the turn of the 1940s and 1950s, he wrote and published in his Belgian pied-à-terre a couple of slim poetry collections in Polish. Whereas these early poems are partially characterized by a tendency toward authenticity (bearing reminiscence, among other things, to the author's "Polish years" and his wartime experiences), they formally seem to reveal a close affinity with literary tradition rather than a commitment to artistic experimentation. ${ }^{3}$ By the middle of the 1950 s, Pankowski made a first cautious step toward the writing of fiction, with the publication of his prose debut Smagta swoboda (Tanned Freedom), a collection of five lyrical and programmatic "treatises" that are deeply immersed in the realities of Polish folk culture and rural life.

A "new" Pankowski would arrive only by the end of the 1950s, along with the release of his next prose book Matuga idzie. Przygody (Here Comes Matuga. Adventures). The 
exalted lyricism of his early writings collides here with the recurring usage of vulgar and erotic elements and becomes deeply embedded in a grotesque evocation of reality. ${ }^{4}$ Along with the auto-ironic gesture of dedicating the book to "Maniuś Pankowski, the author of lyrical poems", the author's disruptive intentions are clearly exemplified in a programmatic text that opens this collection of stories loosely connected around the peregrinations of a young Polish emigrant (Władzio Matuga). Another significant device that comes to the surface in Matuga idzie and that was to become a constant in Pankowski's "mature" fiction is its strong engagement with autobiographism: a great deal of these novels and short stories feature male protagonists who seem to be (at least partly) inspired by the author's own "adventures" (be it as a child and a teenager in interwar Poland, as a Nazi camp prisoner during the Holocaust, or as an émigré professor of Polish literature residing in postwar Western Europe). The meaningful subtitle Adventures in turn exemplifies the close link between Pankowski's prose and the tradition of the picaresque novel: far from being a positive hero who embodies the patriotic ethos and virtues of the postwar Polish émigré community, the main protagonist Matuga is rather an anti-hero and lonely outsider who wanders through a world full of corruption and delusive myths.

To a certain extent, the artistic break heralded by Matuga idzie coincided with a significant shift in Pankowski's attitude toward the Polish émigré circles. ${ }^{5}$ As early as 1953, Pankowski had begun to collaborate with the Paris-based Polish émigré publishing house Instytut Literacki (Literary Institute) and its influential monthly review Kultura (Culture). In opposition to the authoritative Polish circles in London (where the Polish government in exile had its seat), Kultura's publisher and editor in chief Jerzy Giedroyc relied on a small but committed team of collaborators who critically evaluated both the nouveau and the ancien régime (the Polish People's Republic on the one hand and the political constellation of interwar Poland on the other). Apart from regularly contributing to the pages of Kultura (on literary and political issues alike), Pankowski managed to publish the aforementioned Smagła swoboda at Giedroyc's Literary Institute in Paris and even received the first literature prize awarded by its monthly magazine. ${ }^{6}$ The relations between Pankowski and his Parisian publisher started to cool, however, most notably by the end of the 1950 s, when the political climate in Poland itself briefly improved (in the aftermath of the so called Polish October) and Pankowski started to travel between Brussels and his native Sanok. While these intensified ties with the People's Republic hardly could have been an insurmountable obstacle for Giedroyc and his editorial team, more significant importance should be given to the growing artistic disagreements that drew Kultura and Pankowski apart (forcing the latter to publish his second prose book Matuga idzie not with Giedroyc in Paris, but in Brussels on his own).

A similar fate befell Pankowski's next prose collection Kozak i inne opowieści (The Cossack and other stories), which appeared in 1965 in Brussels under the label "Nakładem autora" ("Published through the author's effort"). More favorable publishing opportunities opened up for Pankowski only in the beginning of the 1970s, when he initiated a long-term collaboration with the London-based émigré publisher Oficyna Poetów i Malarzy (Poets' and Painters' Press). Significantly, most of Pankowski's books that came out in London throughout the 1970s and 1980s were subsequently accepted for publication and reprinted by state-supported publishing houses within the People's Republic, usually after a lapse of a couple of years. As such, Pankowski's best-known work of fiction, the aforementioned novel Rudolf, first appeared in London in 1980 and was followed by a Polish edition in 1984. In fact, unlike other émigré writers such as Czesław Miłosz and Witold Gombrowicz (both 
affiliated with Giedroyc's Kultura), Pankowski never met censorship in the People's Republic and was considered to be ideologically acceptable and inoffensive. Undoubtedly, the author's long-lasting ties with his home region and his regular visits to the People's Republic partly explain the relative obligingness of the communist regime in these matters and simultaneously shed light on Pankowski's almost obsessive refusal to be referred to as an "émigré writer" (rather than being described as a "Pole living abroad").

Pankowski's publication track record in the 1970s and 1980s should, however, not convey the impression that his works were warmly received by the Polish readership (be it in Poland or abroad). Although the pre-1989 reception of Pankowski's works still needs thorough investigation ${ }^{7}$, the controversial nature of his literary output - on the level of both form and content - is likely to be one of the main causes of the predominantly lukewarm, if not indignant and dismissive responses to Pankowski's work. More often than not, his prose and theatre pieces tend to upset the reader in the sense that they mercilessly mock at ossified stereotypes and habits, while simultaneously delving into the realm of taboos and transgressive behavior (such as same-sex love and pedophilia). Also, in line with the aesthetic program presented by the author in the preface of his Matuga idzie, Pankowski's narrators and protagonists often venture into various registers of intimate, obscene, and vulgar speech. Paradoxically, despite Pankowski's geographical separation from the Polish readership and from day-to-day spoken language, he managed to turn this obstacle into a benefit and became one of the most creative and reckless innovators of Polish literary speech in the postwar period. $^{8}$

Much of these elements come together in what has perhaps become Pankowski's most emblematic novel, Rudolf. The book tells the story of a middle-aged Polish professor (once again the author's alter ego) who survived the Nazi concentration camps and settled in Brussels. The narrator becomes acquainted with an elderly German homosexual, Rudolf, who shares with him the intimate and candid recollections of his many sexual encounters and gay relationships, while taking a sledgehammer to his interlocutor's placid middle-class way of life, in favor of an existence filled with physical enjoyment and abundant love. The obvious oppositions between the passionate German protagonist and his sedate Polish antagonist are most clearly exposed in a remarkable scene that revolves around the tattoos both men wear. Whereas the Pole bears a concentration camp number on his arm (a silent testimony to the tragic sufferings of WWII), his German opponent ostentatiously discloses the name of a former Arab lover tattooed just below his waistline (which is emblematic of his detachment of worldly affairs).

Interestingly, the relatively limited attention for Pankowski in pre-1989 Poland and among Polonia at the time seems to be inversely proportional to the relative success his prose and theatre gained from the 1960s onwards in several Western European countries. The first translation of Matuga idzie (i.e., a French edition published in Brussels) appeared as early as 1962 and was followed in the 1970s by a series of stagings of Pankowski's theatrical works, mainly in the French-speaking part of Western Europe (France, Belgium, and Switzerland). The late 1970s in turn marked the introduction and popularization of Pankowski as a prose writer in the Netherlands. ${ }^{9}$ Interestingly, while his works became (and remained) prolific in Francophone Europe ${ }^{10}$, this was much less the case in either the German-speaking or the Anglophone area (where up till now only one Pankowski novel has appeared in translation). ${ }^{11}$ Moreover, a closer look at Pankowski's publication track record in French and Dutch over the past four decades and the list of Pankowski stagings by West European theatre companies ${ }^{12}$ 
indicates that the foreign attention for his work reached its apogee in the 1980s and 1990s, after which Pankowski's name seems to have gradually disappeared from the foreign literary radar.

The subsequent rise of interest in Pankowski's work in Poland itself seems to have unfolded in two phases. The early 1990s marked the first attempts of Polish literary scholars to present a more coherent and comprehensive view of Pankowski's literary output. While Stanisław Barć's 1991 monograph strongly focuses on Pankowski as a poet and prose author (with particular attention to the "all-embracing, extraordinarily dynamic biologism" of Pankowski's literary universe), researchers such as Krystyna Latawiec (1994) and Krystyna Ruta-Rutkowska (2001) turned their attention to his theatrical pieces (on the one hand inscribing these works into the wider context of postromantic Polish émigré literature, on the other hand exposing Pankowski's tendency towards dramaturgic experimentation). Significantly, the first decade after the fall of communism revealed an increased interest in Pankowski's plays not only from the part of Polish literary scholars, but also from the part of theatre directors and major Polish publishing houses. ${ }^{13}$

Pankowski's lingering in literary limbo would be halted in a more durable way only after the turn of the millennium, when some of his newly written prose works started to receive nominations for major Polish literary prices. Its most remarkable manifestation is the prose collection $Z$ Auszwicu do Belsen. Przygody (From Auszwic to Belsen. Adventures), which appeared in 2000, more than fifty years after the end of the Second World War. Although references to Pankowski's detainment in several Nazi camps had appeared in some of his earlier works (for instance in his first books of poetry and in the novel Matuga idzie), this was the first book in which he fully exposed his wartime experiences, albeit in fragmentary scenes or - in the author's own words - episodic "adventures". Nominated in 2001 for one of the most prestigious Polish literary awards (the NIKE), the book marked a new step in Pankowski's move from the peripheries of Polish literary life toward its more central regions. Significantly, another NIKE nomination came to Pankowski's next prose book W strone mitości (Towards Love), which appeared only one year later.

While neither of the aforementioned books was eventually awarded the NIKE, the persistent creative drive of the aged Pankowski was symbolically remunerated in 2008 when he became the third laureate of the highly esteemed Literacka Nagroda Gdynia (the Gdynia Literary Award), for his prose book Ostatni zlot aniołów (The Last Convention of Angels). Yet, we would obtain a distorted image of Pankowski's most recent literary successes if we were to ascribe them solely to the author's artistic perseverance and the particular creative outburst that seems to mark the most recent phase of his literary career. Over the past decade, Pankowski's writings have found a considerable number of ardent supporters in circles of young (mainly left-wing) Polish intellectuals and artists. In fact, the first Polish cultural review that decided to devote one of its thematic issues ("Camp, katolicyzm, queer, konsumpcja") to Pankowski was the Krakow-based quarterly Ha!art (2004/18). More recently, the editors of the Ha! art magazine and its publishing house have actively engaged in the promotion of Pankowski's writings in his home country, not only by republishing "classic" novels such as Rudolf and Patnicy z Macierzyzny (The Pilgrims from Motherland), but also by bringing on the literary market newly written books by Pankowski. In a similar vein, Pankowski's literary output has become one of the showpieces of the left-wing Warsaw press associated with "Krytyka polityczna" ("Political Critique"). 
At the occasion of Pankowski's 90th birthday, we invited scholars to a conference entitled "Pan(K)opticum - Exploring the Writings of Marian Pankowski" (Université Libre de Bruxelles, 13-14 November 2009) to reflect on the complexity, richness, and diversity of his literary output. ${ }^{14}$ For the purpose of the conference, Pankowski's oeuvre was symbolically dismantled into the following set of research themes: "Marian Pankowski between languages", "Marian Pankowski beyond norms" and "Marian Pankowski above genres". The first field of research entailed considerations of Pankowski's sumptuous language, the translations he authored as well as editions of his writings in other languages and related issues of translingual interpretation and literary translation. The second research theme linked up with Pankowski's extraordinary biography and the fact that his writings tend to escape established norms, codifications, and classifications. Issues to be explored here included: the position Pankowski's works take up in Poland and abroad, his status of being both a Polish and a Belgian writer / a domestic and an émigré writer, and Pankowski's peculiar way of writing about delicate issues such as Polishness, homosexuality, camp life... The third thematic cluster dealt with the generic diversity of Pankowski's writings (poetry, prose, theatre), the mixture of literary forms (essay, story, novel) as well as the usage of stylistic tricks (innovation, concetto, stylization, pastiche).

If we return briefly to the conference title, we may note that the wordgame in the phrase "Pan(K)opticum" accurately reflects the individuality and unclassifiability of this author, whose nickname among students and insiders is exactly 'Panko'. And the very world that is represented by Panko, according to his specific, unusual view, is fascinating and challenging - at the same time beautiful, and strange, and terrible, and serious, and funny! The author, a little bit like the hero of Bal wdów i wdowców (The Widows' and Widowers' Ball) eludes, fortunately, the catching and enclosing, also by the respectable university scholars, to whom he seems to say, with the humorous contrariness that characterizes him, "fiddle-de-dee". Therefore, some appreciation should be shown to those researchers who dare to write in a scientific way about Marian Pankowski's oeuvre.

For the purpose of this special issue of Russian Literature, we decided to further develop the ideas that were initially presented at the 2009 international conference. As a result of this process, the present selection of ten papers had to be rearranged along a number of new conceptual and interpretive lines. ${ }^{15}$ The first cluster of three papers focuses on the various aspects and functions of gender and sexual identities in Pankowski's writings. By means of a 'revindicative', feminist reading of a selection of Pankowski's works, Inga Iwasiów challenges the "conviction that the transgressive edge of his texts deconstructs gender binaries". The author examines feminine roles in Pankowski's writings within three intersecting areas: the motherland, the bunker as a symbol of hidden, preserved histories, and liberal discourse. She demonstrates that Pankowski's subversion of existing norms does not necessarily imply a complete departure from patriarchal discourse: "While masculinity evades the norm through homosexual code and the experience of the concentration camp, war, and emigration, femininity turns out to be more stable. This is [...] an important paradox: while language, the concept of nation, and social roles change, the phantasms of femininity seem most resilient to change and stand strong against the efforts of deconstruction." Jan Bińczycki, for his part, seems to second some of Iwasiów's thoughts on the subversive power of masculinity in his analysis of male characters in Pankowski's novels Matuga idzie, Rudolf, Putto, and Bal wdów i wdowców (The Widows' and Widowers' Ball), and in his novella Ostatni zlot aniołów (The Last Convention of Angels). Bińczycki argues that in many of 
Pankowski's prose works the formation of male identity is usually associated with certain initiation experiences from early youth and childhood. A surprising reference point in the analysis is Robert Bly's reading of the "Iron John" tale by the Grimm brothers. It turns out that in Pankowski's anthropology "strength is the essence of masculinity - strength that manifests itself in the ability to transcend culture, to survive disappointment, to tear down stereotypes". Last, in her reading of those parts of Pankowski's literary output that deal with concentration camp reality Bożena Shallcross emphasizes the more shady sides of male and, especially, gay identity formation in the already traumatizing circumstances of imprisonment. She contends that, by explicitly focusing on generally marginalized concentration camp figures such as the Schwule, the Pipel, and the Muselmann, Pankowski challenges the dominant martyrological model of describing camp reality and its "well-established pattern of devoicing such non-heroic figures".

The second set of three essays further explores the critical edge of Pankowski's writings by focusing on the various ways in which his texts challenge the norms, myths, and stereotypes that are traditionally associated with Polish and Western European culture. In her article Jolanta Pasterska offers a panoramic overview of Pankowski's literary rebellion against "stereotypical representations of both his motherland and the West". According to her, what is at the centre of Pankowski's reckonings with his native historical, romantic, religious, and corporal taboos and schemata on the one hand, and with the myth of Polish emigration on the other, is the resistance of the individual to "the interference of the "homogenising energy" of the homeland or the foreign land [...] in [his or her] private life". Krystyna Latawiec, for her part, describes Pankowski as a writer who has always taken up a position somewhere in between the Polish Romantic tradition and European rationalism. She argues that this has proven to be personally and artistically fruitful, as it allowed him to fashion himself as both a critical Pole and a critical human being: "For the Poles, he is a "rationalist", who shows the void behind the rituals of their social and religious life, while for a western reader, he is an "anarchist", who abandons the symmetrical Cartesian gardens". Another realm where issues of Polish national identity and of global ethics intersect is that of concentration camp experience. In his article Piotr Krupiński supports Bożena Shallcross's emphasis on the antimartyrological tendency of Pankowski's literary accounts of camp life. Krupiński argues that Pankowski's literary project both reiterates and complements the positions that have been taken up by famous predecessors such as Tadeusz Borowski and Imre Kertész. By focusing on the highly sensitive issues of religion and homosexuality - two revolutions of 'Planet Auschwitz' - the paper demonstrates that Pankowski's texts constitute a strikingly individual engagement with one of the central paradoxes that occupies the anti-martyrological current in Holocaust literature, i.e. that "the camp is shocking not because it constitutes a gap in the surface of civilized reality but because it distinctively starts to merge with this surface".

The authors of the last cluster of essays focus rather on single questions and themes pertaining to Pankowski's literary output. Karolina Felberg takes his 'seniorical' prose (and more exactly the novel Bal wdów $i$ wdowców and the micro-novel "Pismo w stronę miłości" ("Writing Towards Love")) as a starting point for her ruminations on the ways in which the author manages to transform his own experience of ageing from a melancholic into an ecstatic literary experience. Another of Pankowski's 'seniorical' texts, Ostatni zlot aniołów, is at the centre of Krystyna Ruta-Rutkowska's paper on the issue of religion in the author's complete works. Ruta-Rutkowska convincingly argues that religion has always been an important point of reference in Pankowski's literary output, in its sociological and ceremonial, as well as in its 
anthropological and philosophical dimension. Ostatni zlot aniotów offers both a culmination of these aspects and a clear preference for the pragmatic dimension of religion. Although it is tempting to interpret this return to religious issues in the light of the process of ageing, she contends, "it does not bring 'the last word' but rather shows Pankowski's indulgence for religious needs as "beneficial illusions"'. The shared belief that, no matter from what critical angle this peculiar prose is analyzed, it keeps resisting a definitive reading, is approached from a metapoetical and metanarrative point of view in Michał Bandura's paper on the problem of representation in Pankowski's works. By means of a series of well-chosen examples Bandura proves that Pankowski incessantly foregrounds the "crisis of mimesis", either by exposing the various codes which lie at the basis of the process of literary mimesis, or by breaking the narrative frame of his works. Issues that are only briefly touched upon and that demand further examination include the question of autobiographical writing and the problem of representing concentration camp experiences. In the concluding article of this special issue, Przemysław Czapliński resumes many of the issues raised in the previous papers in his discussion of Pankowski's ambiguous position toward the canon (to be understood as "a set of principles determining those articulations that are permitted in a given culture"). Czapliński discerns three subsequent approaches of the canon in Pankowski's prose works: his early attack on the canon with counterofficial contents; the subversive staging, in his more mature novels, of the conflict between the official and the forbidden; and the surprising reaffirmation, in his most recent works, of the canon (to be understood now as "as an individually established set of principles"). As he concludes, this "canon of individual temptation, based on a freedom to self-restriction, is a sort of utopian gift for the new century from the youngest of the oldest writers".

\section{LITERATURE}

Barć, Stanisław

1991 Marian Pankowski. Poeta-Prozaik-Dramaturg. Lublin.

Beers, Paul

2010 “Marian Pankowski's 'lotgevallen' in Nederland". Tijdschrift voor Slavische Literatuur, 55, 30-34.

Goddeeris, Idesbald

2003 "Kultura and Belgium (1947-2000). With particular attention to Maciej Broński”. In: For East is East: liber amicorum Wojciech Skalmowski / Ed. by TatjanaSoldatjenkova and Emmanuel Waegemans. Leuven, 45-73.

Jarzębski, Jerzy

1999 Pożegnanie z emigracją - o powojennej prozie polskiej. Kraków.

Knapp, Bettina L.

1990 „Review of Le Thé au citron”, World Literature Today 64, 494.

Latawiec, Krystyna

1994 Na scenie świata i teatru. O dramaturgii Mariana Pankowskiego. Kraków.

Lambert, Jeremy \& Dorota Walczak

2008 "Entretien avec Marian Pankowski”, Slavica Bruxellensia 1, 41-53.

Mojsak, Kajetan

2008 „'Przygody ciała' - podmiotowość i groteska w powieści 'Matuga idzie' Mariana Pankowskiego", Pamiętnik Literacki, 99/4, 123-144. 


\section{Pankowski, Marian}

1996 Rudolf. Transl. John Maslen and Elizabeth Maslen. Evanston.

Ruta-Rutkowska, Krystyna

2001 Dramaturgia Mariana Pankowskiego. Warszawa.

2008 Szkice o twórczości Mariana Pankowskiego. Warszawa.

\footnotetext{
${ }^{1}$ Cf. Ruta-Rutkowska 2008: 8.
}

${ }^{2}$ This innocence of Pankowski's early lyrics should be put between quotation marks, as Pankowski devoted one of his earliest postwar poems to his concentration camp experiences (cf. Piotr Krupiński's discussion of "Auschwitz" in the present issue).

${ }^{3}$ A detailed discussion of Pankowski's lyrical “juvenilia” can be found in Barć 1991: 13-80.

${ }^{4}$ Cf. Mojsak 2008.

${ }^{5}$ In interviews Pankowski often stresses that he does not want to be perceived as a member of the Polish émigré circles. Cf. Lambert \& Walczak 2008: 43.

${ }^{6}$ For a detailed discussion of Pankowski's ties with Kultura see Goddeeris 2003: 52-56.

${ }^{7}$ Barć 1991: 5-7 provides a short list of articles, reviews, and MA theses that were devoted to Pankowski's writings before 1989 .

${ }^{8}$ Cf. Jarzębski 1999: 79.

${ }^{9}$ Cf. Beers 2010. The Dutch editions of Pankowski's literary output include: Matuga komt (Matuga idzie, 1978), Beukenootje (Bukenocie, 1979), De getaande vrijheid (Smagła swoboda, 1981), Rudolf (1984), De pelgrims uit Uteria (Pątnicy z Macierzyzny, 1986), De Gast (Gość, 1993), De les van Simone (Lekcja Simone, 1997), De planeet Auschwitz. Lotgevallen (Z Oświęcimia do Belsen. Przygody, 1999).

${ }^{10}$ Since the first French edition of Matuga idzie in 1962, more than fifteen Pankowski books have appeared in French translation. These publications include: Théâtre complet 1 (1972), Tout près de l'oeuil (1974), Théâtre complet 2, Rudolf (1982), Matuga (1984), Les pélerins d'Utérie (1986), Le gars de Lvov (1987), Liberté vagabonde (1988), Le thé au citron (1989), Un vieil avenir (1989), Le retour des chauves-souris blanches (1991), L'or funèbre (1993), Putto (1995), Un presbytère en Poméranie (1997), D'Auschwitz à Bergen-Belsen (2000), Post-scriptum à l'amour (2001), Mon Roi vaincu \& Les bras autour du cou (2003).

${ }^{11}$ The only English edition of Pankowski's fiction is the aforementioned 1996 translation of Rudolf. In the German-speaking area, Pankowski was introduced as early as 1972, with the translation of Matuga idzie (Matuga kommt). A German edition of Rudolf is currently being prepared by the Poland-based German translator Sven Sellmer. A similar scarcity seems to exist in literary criticism, except for a couple of enthusiastic reviews in World Literature Today (in one of which Bettina L. Knapp (1990) welcomed Pankowski as a remarkable author who "shows great sensitivity and deftness in handling the most painful situations and evinces considerable humor and joy in describing people who meet, converse, and slowly transcend time/space categories to find themselves in dimensionless climes of memory.")

${ }^{12}$ Cf. Ruta-Rutkowska 2001: 199.

${ }^{13}$ Ruta-Rutkowska (2001: 199) notes that there were at least six stagings of Pankowski plays in the first decade after the fall of communism. Within the same time frame, one of the major Polish publishing houses (Wydawnictwo Literackie) published two books with an extensive selection of Pankowski's theatrical work.

${ }^{14}$ We would like to take this opportunity to express our gratitude to all those who assisted us in organizing this conference: Vanessa Demeuldre, Jeremy Lambert, Marek Pandera, and Katia Vandenborre. Also, this conference would not have been possible without the financial support of the Cultural Service of the Polish Embassy in Belgium, the Research Foundation - Flanders (FWO), the FNRS (Fonds de la Recherche Scientifique), and the departments of Polish/Slavic studies at the universities of Brussels (ULB), Ghent (UGent), and Leuven (KULeuven).

${ }^{15}$ The present issue would not have been possible without the valuable support of our proofreader, Jack J. Hutchens, who not only helped us with copyediting the subsequent papers, but who also (himself being a scholar of Pankowski's works) translated the article by Przemysław Czapliński. 